\title{
КРИМІНАЛЬНА ВІДПОВІДАЛЬНІСТЬ НОТАРІУСА ЗА ВЧИНЕННЯ ЗЛОЧИНУ, ПЕРЕДБАЧЕНОГО СТ.365-2 КРИМІНАЛЬНОГО КОДЕКСУ УКРАЇНИ
}

\author{
ШЕВЧУК Н.В. - кандидат філософських наук, доцент, юридичний \\ факультет Свропейського університету \\ ЩЕБЕЛЬ А.І. - студенТ магістратури, юридичний факультет Свропейського \\ університету \\ ГЕВКО О.О. - студент магістратури, юридичний факультет Свропейського \\ університету
}

DOI 10.32782/EP.2021.4.18

У статті аналізуються питання кримінальної відповідальності за вчинення злочину, передбаченого ст.365-2 Кримінального кодексу Украӥни. Відповідальність нотаріуса за зловживання своїми повноваженнями з метою отримання неправомірної вигоди передбачена у Розділі XVII «Кримінальні правопорушення у сбері службової діяльності та професійної діяльності, пов'язаної з наданням публічних послуг» КК Украйни. Обгрунтовано, що безпосереднім об’єктом складу злочину, передбаченого ст.365-2 КК України, слід визнавати суспільні відносини, які покликані забезпечувати законну діяльність осіб, які здійснюють професійну діяльність, пов'язану з наданням публічних послуг.

Констатовано, що склад злочину «зловживання повноваженнями особами, які надають публічні послуги» $\epsilon$ матеріальним, а отже, відповідальність за вчинені дї наступає у випадку спричинення наслідків у виді icтотної шкоди охоронюваним законом правам або інтересам окремих громадян, державним чи громадським інтересам або інтересам юридичних осіб (и.1 cm.365-2 КК України) або спричинення тяжких наслідків. 3 аналізу диспозииї статті встановлено, що ставлення особи, яка надає публічні послуги, до злочинного діяння характеризується умисною фбормою вини у виді прямого умислу, тоді як до наслідків - як умисною, так і необережною.

Ключові слова: нотаріальна діяльність, кримінальна відповідальність, нотаріус, спеизільний суб'єкт злочину.

\section{Постановка проблеми}

Наукове дослідження будь-якої проблеми здійснюється у певній логічній послідовності та, насамперед, передбачає пошук i аналіз відповідного матеріалу, що дає змогу систематизувати та узагальнити увесь обсяг теоретичних напрацювань [1, с.118]. Не є винятком у цьому випадку і питання кримінальної відповідальності нотаріуса, оскільки нотаріальна діяльність $є$ важливим елементом механізму держави, забезпечує реалізацію значного комплексу прав юридичних осіб, прав і свобод фізичних осіб. Окрім того, нотаріальне посвідчення юридично значущих фактів і документів $\epsilon$ необхідною умовою виникнення, зміни та припинення багатьох правовідносин. На індивідуальному рівні діяльність нотаріату зазвичай зачіпає права та законні інтереси, які стосуються майнових i немайнових благ, що забезпечують природне та соціальне буття людини, у разі втрати чи іншого ураження яких відновити попередній стан або вкрай важко, або взагалі неможливо $[2$, c.9].

Аналіз правозастосовної практики свідчить про те, що кримінально-правові норми, які регламентують відповідальність за порушення, допущені в ході нотаріальної діяльності, застосовуються вкрай рідко і не дозволяють забезпечити ефективну охорону відносин, які регламентують порядок надання нотаріальних послуг. Такий стан речей може свідчити про те, що до статистичної звітності потрапляють не всі злочини, вчинені но- 
таріусами, а тільки частина 3 них, решта не зареєстрована й становить, таким чином, латентну злочинність. У свою чергу, високий рівень латентності відповідної групи злочинів неминуче викликає їх примноження через нівелювання принципу невідворотності відповідальності.

\section{Стан теоретичного дослідження}

Дослідження питань кримінальної відповідальності нотаріуса, не знайшло свого детального розроблення у кримінально-правовій літературі. Це пов'язано власне з тим, що, як правило, це питання розглядалося науковцями лише при кримінально-правовій характеристиці окремих складів злочинів або їх ознак. Так, О.В. Коротюк на дисертаційному рівні проаналізував питання нотаріуса як спеціального суб'єкта кримінального правопорушення, визначено правовий статус державних і приватних нотаріусів, аргументовано необхідність і соціальну обумовленість кримінально-правових положень, що позначають нотаріуса спеціальним суб'єктом, а також встановлено їх відповідність підставам та принципам криміналізації [3]. Вартою уваги є праця Ю.О. Шиндель, у якій розкрито особливості кримінально-правової характеристики зловживання повноваженнями особами, які надають публічні послуги, а також розроблено та обгрунтовано пропозиції щодо вдосконалення закону України про кримінальну відповідальність за зловживання повноваженнями особами, які надають публічні послуги, та вироблено наукові рекомендації стосовно кваліфікації зазначеної протиправної поведінки [4].

Не можна не згадати дослідження І.П. Фріca, у якому вивчалось питання кримінальноправового забезпечення охорони нотаріальної діяльності. Зокрема, автором проаналізовано основні методологічні в цій частині, розглянуто історичні та компаративістські аспекти кримінально-правового забезпечення охорони нотаріальної діяльності, а також питання кримінальної відповідальності нотаріуса за порушення норм нотаріального процесу [5]. Водночас питання кримінальної відповідальності нотаріуса як суб'єкта кримінального правопорушення, передбаченого ст.365-2 КК України, не можна назвати вичерпними.
Незважаючи на те, що певні аспекти цього питання є загальновизнаними, втім інші залишаються недостатньо висвітленими. Так, скажімо, не існує єдності позицій з приводу визначення змісту поняття «публічні послуги». Дискусійним залишається питання щодо визначення форм злочинного діяння нотаріуса, яке передбачене у ст. 365-2 КК України.

3 огляду на зазначене метою цієї статті є вивчення питань кримінальної відповідальності нотаріуса як суб'єкта кримінального правопорушення, передбаченого ст.365-2 КК України.

\section{Виклад основних положень}

Відповідно до ЗУ «Про внесення змін до деяких законодавчих актів України щодо відповідальності за корупційні правопорушення» від 7 квітня 2011 р. КК України було доповнено статтею, яка регламентує відповідальність за зловживання повноваженнями особами, які надають публічні послуги. Необхідність криміналізації цих діянь за твердженням М.В. Саламатової назрівала вже давно, оскільки нотаріуси не є представниками влади або місцевого самоврядування, і тому не були суб'єктами кримінальних правопорушень, передбачених ст. ст. 364, 365, 368 КК України, що на практиці нерідко створювало можливість уникати відповідальності [6, с.75]. Окрім того, на думку цього автора, включення нотаріусів до кола суб'єктів корупційного правопорушення було правильним кроком законодавця з огляду на рух законодавства в напрямі наділення нотаріусів повноваженнями не просто публічного, а й владного характеру. Особливості правового статусу нотаріуса, характер його повноважень та юридичне значення нотаріальних дій свідчать про якісно інший характер суспільної небезпечності кримінальних правопорушень у сфері нотаріальної діяльності, а ії ступінь є значно вищим за суспільну небезпечність зловживання повноваженнями 3 боку інших суб'єктів надання публічних послуг (аудиторів, арбітражних керуючих, оцінювачів, експертів тощо)$[2$, c.8].

Незважаючи на широкий спектр надання нотаріальних послуг та їх поширеність (приміром за 2013-2014 рр. нотаріуси посвідчували близько 12 млн. правочинів на рік на суму 


\section{Кримінальне право, кримінальний процес та криміналістика}

близько 3 млрд. грн., що є свідченням того, що третина населення України хоча б один раз ставала причетною до нотаріальної діяльності), офіційній статистиці відомі дані лише про мізерну кількість кримінальних правопорушень, що вчиняються нотаріусами щороку. У той же час за експертними оцінками, близько 5\% нотаріусів періодично вдаються до протиправних дій [2, с.45].

Слід зазначити, що відповідальність нотаріуса за зловживання своїми повноваженнями 3 метою отримання неправомірної вигоди передбачена у Розділі XVII «Кримінальні правопорушення у сфері службової діяльності та професійної діяльності, пов’язаної з наданням публічних послуг» КК України. Професійна діяльність осіб, які надають публічні послуги, зокрема й нотаріуса, повинна базуватися виключно на вимогах законодавства України, а тому нотаріуси мають бути незалежними та об'єктивними. Втім, не виключені випадки зловживань з їх сторони з метою отримати неправомірну вигоду, наслідком чого є порушення прав громадян, інтересів юридичних осіб, що створює загрозу стабільності демократичних інститутів. Окрім того, за твердженням М.Б. Желіка, прийняття пропозиції, обіцянки або одержання неправомірної винагороди породжує у громадян та суспільства уявлення стосовно можливості досягнення бажаного результату шляхом підкупу осіб, які надають публічні послуги, для яких така винагорода є джерелом незаконних доходів, що руйнує чесність та соціальну справедливість [7, с.74]. А тому безпосереднім об'єктом злочину, передбаченого ст.365-2 КК України, слід визнавати суспільні відносини, які покликані забезпечувати законну діяльність осіб, які здійснюють професійну діяльність, пов'язану з наданням публічних послуг.

Склад злочину «зловживання повноваженнями особами, які надають публічні послуги» 6 матеріальним, а отже, відповідальність за вчинені дії наступає у випадку спричинення наслідків у виді істотної шкоди охоронюваним законом правам або інтересам окремих громадян, державним чи громадським інтересам або інтересам юридичних осіб (ч.1 ст.365-2 КК України) або спричинення тяжких наслідків (ч.3 ст.365-2 КК України). Злочинними визнаються не будь-які ді- яння нотаріуса, а лише ті, що пов'язані з його професійною діяльністю. Так, зловживанням з боку нотаріуса слід вважати розголошення таємних відомостей, які були одержані ним у зв’язку з вчиненням нотаріальних дій або вчинення нотаріальної дії в разі ії невідповідності законодавству України тощо.

Обов'язковою ознакою об'єктивної сторони складу злочину, передбаченого ч.1 ст.3652 КК України, є спричинення діями нотаріуса істотної шкоди. Відповідно до примітки до ст.364 КК України істотною слід вважати шкоду, яка в сто і більше разів перевищує неоподатковуваний мінімум доходів громадян. Так, відповідно до ЗУ «Про державний бюджет України на 2021 рік» від 15 грудня 2020 р. прожитковий мінімум на працездатних осіб з 1 липня 2021 року становить 2379 гривень. 3 огляду на це, розмір істотної шкоди заподіяної внаслідок зловживання повноваженнями особами, які надають публічні послуги, складатиме 118950 грн. Особливо кваліфікуючою ознакою вчинення аналізованого посягання є спричинення тяжких наслідків, які, як і істотна шкода, вважаються оцінними поняттями. Відповідно до примітки до ст.364 КК України тяжкими є наслідки, які у двісті п’ятдесят і більше разів перевищують неоподатковуваний мінімум доходів громадян. А тому їх розмір становитиме 297375 грн.

Суб'єкт злочину, передбачений ст.365-2 КК України, є спеціальним. Ним є особа, яка надає публічні послуги, зокрема й нотаріус. Відповідно до ст.3 ЗУ «Про нотаріат» від 2 вересня 1993 р. нотаріусом є уповноважена державою фізична особа, яка здійснює нотаріальну діяльність у державній нотаріальній конторі, державному нотаріальному архіві або незалежну професійну нотаріальну діяльність, зокрема посвідчує права, а також факти, що мають юридичне значення, та вчиняє інші нотаріальні дії, передбачені законом, 3 метою надання їм юридичної вірогідності. Нотаріусом може бути громадянин України, якому присуджено ступінь вищої юридичної освіти не нижче магістра, який володіє державною мовою, має стаж роботи у сфері права не менш як шість років, з них помічником нотаріуса або консультантом державної нотаріальної контори - не менш як три роки, склав кваліфікаційний іспит і отримав свідо- 
цтво про право на зайняття нотаріальною діяльністю (ст.3).

Нотаріус у своїй діяльності зобов'язаний: здійснювати свої професійні обов'язки відповідно до Закону і принесеної присяги, дотримуватися правил професійної етики; сприяти фізичним та юридичним особам у здійсненні їх прав та захисті законних інтересів, роз'яснювати права і обов'язки, попереджати про наслідки вчинюваних нотаріальних дій для того, щоб юридична необізнаність не могла бути використана їм на шкоду; зберігати в таємниці відомості, одержані ним у зв'язку з вчиненням нотаріальних дій; відмовити у вчиненні нотаріальної дії в разі іiі невідповідності законодавству України або міжнародним договорам; вести нотаріальне діловодство та архів нотаріуса відповідно до встановлених правил; надавати документи, інформацію і пояснення на вимогу Міністерства юстиції України, його територіальних органів при здійсненні ними повноважень щодо контролю за організацією діяльності та виконанням нотаріусами правил нотаріального діловодства (ст.5).

У кримінально-правовій літературі триває дискусія щодо змісту поняття публічних послуг. Так, одні автори до цих послуг відносять такі, що надаються публічним або в окремих випадках - приватним сектором під відповідальність публічного сектора i за рахунок публічних коштів [8, с. 76]. Натомість, інші займають дещо іншу позицію і стверджують, що публічними є ті послуги, які є загальнодоступними, мають юридично значущий характер та спрямовані на захист чи забезпечення умов для реалізації суспільних інтересів, прав та інтересів фізичних або юридичних осіб [9, с. 5-6]. Видається, що кожна 3 наведених позицій $є$ правильною, оскільки справді публічні послуги можуть надаватись як публічним, так і приватним сектором (скажімо, посвідчення заповіту приватним нотаріусом або нотаріусом державної нотаріальної контори). Окрім того вони є загальнодоступними, оскільки будь-яка особа має право звернутися до нотаріуса для реалізації своїх прав та законних інтересів. Втім, найбільш повно розкриті ознаки публічних послуг у праці М.Б. Желіка, а саме: 1) надаються публічним сектором а в окремих випадках - приватним під відповідальність публічної влади на звернення заінтересованої особи; 2) спрямовані на реалізацію прав, законних інтересів і виконанням обов'язків фізичними або юридичними особами або пов'язані зі створенням організаційних умов; 3) породжують наслідки правового характеру; 4) надаються у процесі професійної діяльності особами, які відповідають встановленим кваліфікаційним вимогам, що підтверджують право займатись наданням відповідних послуг; 5) порядок і форма їх надання регламентуються законодавством України та перебуває під наглядом держави [7, с.72]. У той же час Ю.І.Шиндель звертає увагу на те, що через відсутність відповідного законодавчого акта щодо врегулювання та визначення сутності таких послуг наукові підходи щодо тлумачення цього поняття не можуть свідчити про об'єктивне існування суспільних відносин, які забезпечують здійснення регламентованої законодавством професійної діяльності, пов’ язаної з наданням публічних послуг$[4$, c. 87$]$.

У подальшому необхідно зупинитись на аналізі суб'єктивної сторони складу злочину, передбаченого ст.365-2 КК України. Її встановлення через низку ознак має важливе значення для кваліфікації кримінального правопорушення та призначення покарання, оскільки дає можливість відмежувати протиправну поведінку від невинно заподіяної шкоди [10, с.67]. Вина, як основна ознака суб'єктивної сторони складу кримінального правопорушення, характеризується психічним ставленням особи до вчинюваної дії чи бездіяльності, а також іiі наслідків, виражене у формі умислу або необережності (ст.23 КК України). 3 аналізу диспозиції статті випливає, що ставлення особи, яка надає публічні послуги, до злочинного діяння характеризується умисною формою вини у виді прямого умислу, оскільки, скажімо, беручи участь у незаконній приватизації та продажу нерухомості (наприклад, посвідчення угоди з померлою особою), нотаріус усвідомлює, що діє всупереч Закону. При цьому ставлення нотаріуса до наслідків вчинення злочину може бути як умисним, так і необережним. Обов'язковою ознакою вини також виступає корислива мета - отримання неправомірної вигоди. Її розглядають як уявний і бажаний суб'єктом кінцевий шкідливий результат, якого вона 
прагне досягнути, вчиняючи протиправне діяння [11, с. 294].

\section{Висновки}

Нотаріат є важливим елементом механізму держави, а відтак його значущість постійно зростає. На нотаріусів покладено обов'язок посвідчення прав, а також відповідних фактів, які мають юридичне значення. У випадку недоброчесності нотаріуса порушуються права та інтереси окремих громадян, юридичних осіб чи держави. А тому держава в особі компетентних органів повинна створити надійний механізм протидії злочинним проявам нотаріальної діяльності.

\section{Література}

1. Олійник Х.В. Стан теоретичного дослідження питань кримінальної відповідальності за пропаганду, планування, підготовку, розв'язання та ведення агресивної війни.Вісник Аьвівського торговельно-економічного університету / [ред.кол.:Щур Б. В., Котуха О. С. та ін.]. Аьвів : Видавництво Аьвівського торговельно-економічного університету, 2019. Вип. 8. С.117-124

2. Саламатова М.В. Кримінологічна характеристика та запобігання злочинам у сфері нотаріальної діяльності. Класичний приватний університет, м.Запоріжжя. 2015 р. 245 с.

3. Коротюк О.В. Нотаріус як спеціальний суб'єкт злочину / дис. канд. юрид. наук: 12.00.08, Акад. адвокатури України. К., 2014.238 c.

4. Шиндель Ю. І. Кримінально-правова характеристика зловживання повноваженнями особами, які надають публічні послуги / дис. ... канд. юрид. наук : 12.00.08 / Харків. нац. ун-т внутр. справ. - Харків, 2014. 244 с.

5. Фріс I. П. Кримінально-правове забезпечення охорони нотаріальної діяльності в Україні : автореф. дис. на здобуття наук. ступеня канд. юрид. наук : спец. 12.00.08; ДВНЗ «Прикарпатський нац. ун-т ім. Василя Стефаника». - Івано-Франківськ, 2015. 18 с.

6. Саламатова М.В. Злочини і злочинність у сфері нотаріальної діяльності. Науковий вісник Ужгородсъкого національного університету. 2014 p. C. $69-75$

7. Желік М.Б. Прийняття пропозиції, обіцянки або одержання неправомірної вигоди:

\section{SUMMARY}

The article analyzes the issue of criminal liability for the crime envisaged in Article 365-2 of the Criminal Code of Ukraine. The liability of the notary for abuse of his authority for the purpose of obtaining an illegal benefit is provided in Chapter XVII "Criminal offenses in the sphere of service and professional activity connected with the provision of public services" of the Criminal Code of Ukraine. It is justified that the direct object of the crime, provided for by Article 365-2 of the Criminal Code of Ukraine, should recognize the public relations, which are intended to provide legal activity of persons who carry out professional activities connected with the provision of public services.

It is stipulated that the crime "abuse of authority by persons providing public services" is material and therefore liability for the actions taken in case of consequences in the form of a significant harm to the rights or interests of individual citizens, state or public interests or interests of legal entities protected by law (part 1 of Article 365-2 of the Criminal Code of Ukraine) or causing serious consequences. The analysis of the article's dispositions revealed that the attitude of the person who provides public services to the criminal act is characterized by a clever form of blame in the form of direct misfortune, whereas the consequences - both clever and careless.

Key words: notarial activity, criminal responsibility, notary, special subject of crime.

кримінально-правова характеристика: дис. ... канд. юрид. наук : 12.00.08 / Нац. ун-т «Львів. політехніка». Аьвів, 2018. 247 с.

8. Хавронюк М. I. Науково -практичний коментар до Закону України «Про засади запобігання корупції / M.I. Хавронюк. - К.: Атака, 2011. 424 с.

9. Тютюгін В. I. Новели кримінального законодавства щодо посилення відповідальності за корупційні злочини: вирішення проблем чи проблем для вирішення ? Юридичний вісник Украӥни. 2010. № 5. С.5-13

10. Кримінальне право України. Загальна частина: Практикум: Навчальний посібник / І.П. Козаченко, О.М. Костенко, В.К. Матвійчук , та ін.- К.: КНТ, 2006. 432 с.

11. Грищук В.К. Кримінальне право України. Загальна частина: навч. посіб. для студентів юрид. фак. вищ. навч. Закл / В.К. Грищук. - К.: Видавничий дім «Ін Юре», 2006. 568 c. 